\title{
Restorative Justice: A Systematic Review of the Social Work Literature
}

\author{
Edward J. Gumz \\ Loyola University Chicago, egumz@luc.edu
}

Cynthia L. Grant

Loyola University Chicago

Follow this and additional works at: https://ecommons.luc.edu/socialwork_facpubs

Part of the Social Work Commons

\section{Recommended Citation}

Restorative Justice: A Systematic Review of the Social Work Literature Edward J. Gumz \& Cynthia L. Grant Families in Society, 2009, v. 90, no. 1 DOI: 10.1606/1044-3894.3853

This Article is brought to you for free and open access by the Faculty Publications and Other Works by Department at Loyola eCommons. It has been accepted for inclusion in Social Work: School of Social Work Faculty Publications and Other Works by an authorized administrator of Loyola eCommons. For more information, please contact ecommons@luc.edu.

\section{(c) $(1) \ominus$}

This work is licensed under a Creative Commons Attribution-Noncommercial-No Derivative Works 3.0 License.

(c) Alliance for Children and Families, 2009 


\title{
Restorative Justice: A Systematic Review of the Social Work Literature
}

\author{
Edward J. Gumz \& Cynthia L. Grant
}

\begin{abstract}
Restorative justice is an alternative paradigm for dealing with the effects of crime and wrongdoing that seeks to bring healing to victims, offenders, and the community. Although a key element of social work's ethical code is the obligation to work toward social justice, this has been viewed primarily as efforts to ensure a fair distribution of resources and opportunities. Yet justice is also restorative in nature-seeking to restore and enhance victims, offenders, and communities to fuller functioning. This article systematically reviews 80 social work peer-reviewed articles dealing with restorative justice. The role of social workers in restorative justice programs remains largely unknown. Suggestions are made for enhancing social work practice in the restorative justice arena.
\end{abstract}

S ince its beginnings as a profession in 19th century America, the mission of the social work profession has been rooted in a set of core values. These core values are service, social justice, dignity and worth of the human person, importance of human relationships, integrity, and competence (Dofgoff, Loewenberg, \& Harrington, 2005), which have been affirmed by social workers throughout its history and are the foundation for social work's unique perspective. The core value of social justice is based on the ethical principal that social workers challenge injustice at the individual, group, and institutional levels. This means social workers pursue social change, particularly on behalf of, but also in concert with, vulnerable and oppressed populations and social structures. Within the context of working toward social justice, social workers have an ideal opportunity to become more involved in the practice of restorative justice.

The current approach to crime, as Stinchcomb and Fox (1999) point out, "does little to reinforce any sense of either personal responsibility on the part of the offender or personal involvement in the justice process on the part of the victim" (p. 652). The traditional justice system utilizes a one-dimensional adversarial approach with attention given primarily to the offender. With an estimated 2 million adults currently incarcerated in the United States and more than $\$ 3$ billion currently spent on imprisonment of persons who are considered to be at a low risk of reoffending (Golder, Ivanoff, Cloud, Besel, McKiernan, Bratt, \& Bledsoe, 2005), there is an urgent need for alternative approaches to crime in this country. Golder et al. poignantly state, "Continued reliance on incarceration (i.e., incapacitation) as the primary strategy for reducing crime is not only expensive monetarily, but it has particularly deleterious effects on poor, urban communities, especially communities of color" (p. 104).

The practice of restorative justice offers victims, offenders, and communities an alternative approach for dealing with the harm caused by crime. In contrast to the aforementioned orientation, restorative justice allows a three-dimensional approach that includes the victim, offender, and community (Bazemore, 1999). This trend away from the current criminal justice system (especially in regard to juvenile delinquency) may allow for comprehensive healing and intervention with all parties impacted by a crime. Restorative justice practices thus offer the potential for decreased recidivism of offenders, fewer long-term effects of victimization, and strengthening of the aggregate well-being of a community. Hence, a threedimensional approach to crime benefits all parties involved.

Historically, restorative justice has its roots in the indigenous rituals of New Zealand communities where shaming of the offender was used as punishment for wrongdoings. Minority 
communities-including African American, Latino, Canadian Mennonite, and Native American-have also engaged in various restorative justice practices for many years. Howard Zehr (2002) has been called the grandfather of the restorative justice movement. He has written extensively on the topic and his book Changing Lenses: A New Focus for Crime and Justice (1990) is considered a classic in the field. In his popular book The Little Book of Restorative Justice (2002), Zehr refers to the three pillars of restorative justice:

Restorative justice focuses on crime done to individuals and communities, with the harm to victims, offenders, and the community in need of healing.

Wrongs and offenses to victims mean that offenders need to be held accountable and responsible.

Restorative justice principles emphasize the importance of victims, offenders, and the community to be involved in a dialogue about what justice means in a particular case.

In summarizing Zehr's work, Bazemore (1999) states,

Howard Zehr (1990) describes the restorative justice paradigm as a new "lens" for viewing the problem of crime and a new value system for thinking about the justice response to offense behavior. Rather than the question of guilt and what should be done to punish or treat the offender, restorative justice suggests that the most important fact about crime is that it causes harm to individuals and communities. "Justice" should, therefore, focus on the repair of this harm. (p. 298)

Zehr writes of restorative justice from a religious and sociological perspective and is internationally known for helping to establish restorative justice as a social movement. In the field of social work, Katharine van Wormer, who is both a sociologist and a social worker, strongly asserts restorative justice falls under the general rubric of social justice, consistent with the Code of Ethics of the National Association of Social Workers (1996). Van Wormer (2002) describes restorative justice as a practice that requires societal institutions to work to repair the damage to those who have been injured and states those most directly affected by crime (including victims and family members) should have the voluntary opportunity to participate in the response to crime.

If social work as a profession is concerned about justice and furthering both social and restorative justice, how do social work scholars understand the principles of and engage in the practice of restorative justice, and how do these elements relate to key issues in the social work profession? This study was conducted to answer this question through a systematic review of the social work literature on the topic of restorative justice from 1995-2007. The review is organized to explore the literature on restorative justice in five dimensions: theory, practice, religion and spirituality, research, and social work education.

\section{Methodology}

We searched databases for articles written about restorative justice in the social work literature dating from January 1977 to Janu- ary 2007; the most recent year available at the time we began our review. Our search specifically targeted articles using the keyword restorative justice as a subject heading. Initially, the authors searched Social Work Abstracts and netted a mere 8 citations, which failed to capture even the first author's previously published article on the subject (Gumz, 2004). A similar literature search conducted by van Wormer in 2003 resulted in only 4 articles (2004). Based on our belief more articles could be located, a new search using the same keyword in Social Services Abstracts yielded 118 published works.

We excluded book reviews, dissertations, and articles written in languages other than English. We only reviewed published, refereed journal articles. Exhaustive attempts to locate each of the remaining articles (including peer-reviewed journal articles from the original Social Work Abstracts database) resulted in our systematic review of 80 restorative justice articles in social work publications. A total of 42 social work journals are represented in this review, including one journal that devoted an entire issue to the topic of restorative justice (Journal of Sociology and Social Welfare, March 2004). It should be noted although the Social Services Abstracts and Social Work Abstracts databases date back to January 1977, the earliest article written on the topic of restorative justice located in this search is from February 1995 (Nellis).

We initially read a sample of 27 articles found through the search of Social Services Abstracts to identify general coding categories. Themes in the literature were identified from the article title or abstract. The initial restorative justice themes were then expanded to include 17 categories of focus in the social work literature. Sample coding topics included the history of restorative justice, theories of restorative justice, practice approaches, spirituality and religion, research, social work role and education, policy, and population of focus for each article. We also identified whether the article focused on restorative justice in the United States or in an international setting.

At the start of the review process, we mutually created definitions of each category. To maximize interrater agreement and to strengthen the consistency of our coding strategies, each of us randomly selected four articles previously coded by the other and coded the article anew based on previously defined categories. Interrater reliability was consistently high. Interval meetings were held by the authors to discuss categorical evolution, to monitor progress of readings, and to identify overlap of content. Article topics overlapped frequently. Each article was coded for the presence or absence of 17 categories. The quantified data was then entered into an SPSS database for descriptive purposes (Statistical Package for the Social Sciences, Version 15.0).

One disclaimer must be made about our methodology. The data collected for this systematic review is based almost exclusively on literature located in social work databases. No attempt is made by the authors to profess this material is exhaustive of all the literature available on the topic of restorative justice. Nugent, Umbreit, Wiinamaki, \& Paddock (2001) have succinctly reported the tremendous growth in the criminal justice literature on restorative justice. Yet with a few notable exceptions (including Katharine van Wormer and Mark Umbreit) social workers have been slow to become involved in practicing, writing, and researching about restorative justice. As social work educators and clinicians, we believe there is significant value in exploring and describing the literature on restorative justice as it is presented in social work databases. What follows is a summary of our review of the social work literature. 


\section{Restorative Justice Theories}

Social work scholars have written little about theories of restorative justice $(15 \%, n=12)$ but what has been written is instructive and shows linkages between restorative justice and its value in social work. Van Wormer (2004) discusses the relationship between social justice-one of the core values of social work-and restorative justice. The usual meaning of social justice in the social work literature is distributive in nature, meaning scarce resources in society are distributed with a focus on equal opportunity for all. Van Wormer (2003) applies these principles to restorative justice (not to social justice), so that justice is provided to the offender, victim, and community. In this way, "restorative justice can be considered a form of social justice because of its fairness to all parties" (van Wormer, 2003, p. 13).

Burford and Adams (2004) assert key theoretical elements in social work involve the relationships between formal and informal helping, care and social control, or empowerment and coercion. These are also restorative justice principles that parallel hallmark social work theories including the person-in-environment perspective found in the writings of pioneers Charlotte Towle (1965), Jane Addams (1912), and Florence Hollis (1964). The concept of responsive regulations, presented by Australian criminologist and renowned restorative justice author John Braithwaite, illustrates the possibilities of restorative, dialogue-based, empowering approaches at one level, and in gradual degrees escalates to more coercive, deterrent strategies. Similarly, social work plays dual roles of social care and social control. As Braithwaite (2004) stated,

social work practice is about empowerment to coax and caress the socially responsible self to the fore. It is about building democratic problem solving, but equally it is about enforcing the democracy's human rights and freedoms when democratic deliberation fails to honor them. (p. 214)

Braithwaite's explication of the social work profession corresponds to Specht \& Courtney's proclamations in Unfaithful Angels (1994) that social workers must collaborate with community groups to aid the individual but also to strengthen the community's ability to problem-solve. Hence, the mission of social work and restorative justice practices appear to be in harmony. The social work scholar Chatterjee (2002) has written about five types of justice. Justice is a form of group behavior that reflects the culture of the group. He discusses corrective and protective justice, which deal with social control and help strengthen existing social order. Distributive and representational justice helps marginalized and disadvantaged members of a group through a more equitable distribution of resources. Restorative justice is in the middle of the aforementioned types of justice; it is a systematic response to wrongdoing that emphasizes healing the wounds of victims, offenders, and communities caused by crime. Therefore restorative justice seeks to transform the traditional criminal justice approach of society's response to crime (Van Ness, 2004).

Van Wormer \& Bednar (2002) offer an excellent bridge between restorative justice and the strengths perspective, which is a widely used social work approach that taps into client capabilities and positive characteristics as a vehicle for change and improved coping. An integrated theoretical understanding applied to battering males is termed "the restorative-strengths approach" and offers a new application for social work practice with these offenders.

One theoretical critique of restorative justice involves the egalitarian attention to the community, victim, and offender. Arrigo (2004) examines community and restorative justice from the perspective of postmodern theory and argues restorative justice is a micro-level process, whereas crime has larger macrolevel implications for society. Arrigo further states to equate the macro- and community-level impact of crime with the micro-level healing aspects of restorative justice would dilute and undermine the nature of restorative justice. Hence, a conundrum emerges in which theorists attempt to merge micro- and macro-level impacts of wrongdoings. This phenomenon is also present in the social work profession's risk of dichotomizing "private troubles versus public issues."

\section{The Practice of Restorative Justice}

Restorative justice is often used as an umbrella term for a wide variety of practice approaches (Tschudi \& Reichelt, 2004). Though practices are often used in a mutually exclusive manner, distinctions across categories have begun to blur (Umbreit, Vos, \& Coates, 2004). The three types of restorative justice dialogue explored in this article are victim-offender mediation (VOM), family group conferencing (FGC), and peacemaking circles.

Literature in our systematic review consistently yielded coverage of the practice of restorative justice among the various approaches. VOM was addressed in $35.5 \%(n=27)$ of all articles reviewed containing restorative justice practices. FGC was discussed in $23.9 \%(n=25)$ of the articles. Peacemaking circles were explored in $18.4 \%(n=14)$ of the articles. Some articles did not address a particular restorative justice approach.

\section{Victim-Offender Mediation}

The first VOM program in the United States, the Victim Offender Reconciliation Program, began in Elkhart, IN in 1978 (Zehr, 2002). The Victim Offender Mediation Association (www.voma.org) reports there are more than 1,200 known restorative justice programs in North America and Europe (Nugent et al., 2001). VOM is the most common type of restorative justice practice utilized in the United States, which is consistent with our review of the prevalence of the literature available on the topic $(35.5 \%, n=27)$. VOM is a face-to-face meeting involving a trained mediator, crime victim, and person who committed the crime. During the meeting the offender and the victim may speak to each other "about what happened, the effects of the crime on their lives, and their feelings about it. They may choose to create a mutually agreeable plan to repair any damages that occurred as a result of the crime" (Ruth-Heffelbower, 2006). Mediators may be community-member volunteers, clergy, criminal justice professionals, or social workers who have become increasingly involved in the practice (van Wormer, 2003). Umbreit and Greenwood's 1998 survey (described in Nugent et al., 2001) reported approximately $80 \%$ of VOM programs in the United States rely on "a VOM model in which mediators meet alone with the victim and alone with the offender prior to a face-to-face meeting" (p. 19). Thus, there is extensive case preparation required before interactions begin between the victim and offender, which makes the implementation of the practice very time-consuming.

The process involved in VOM "humanizes the criminal justice 
experience for both victim and offender" (Umbreit, Bradshaw, \& Coates, 1999, p. 322) through the use of open communication of all parties involved. This experience has been shown to result in high levels of satisfaction with the practice. In a multisite, multiyear study conducted by Umbreit in 1998, 100\% of victims and offenders were very satisfied with their overall involvement in VOM (as cited in Umbreit, Bradshaw, \& Coates, 1999).

The practice of VOM is most often applied with less serious offenses such as nonviolent property crimes with juvenile offenders, but has recently been utilized with more severe offenses (Walgrave, 1995). There is some concern of appropriately applying VOM. The use of VOM with victims of severe crime (murder or domestic violence) may lead to "unintended negative consequences" such as revictimization of a victim or family of the victim if restorative justice practices are not used cautiously (Umbreit, Bradshaw, \& Coates, 1999, p. 340).

\section{Family Group Conferencing}

FGC, also called restorative conferencing (Hillian et al., 2004), was adapted from traditional practices of the Maori people. This practice is slightly different from VOM in that it involves more persons. In addition to the victim and offender, secondary victims (family members, friends, and supporters of the victim) and offender are included (Van Ness, 2004). Van Ness (2004) reports, "These people are involved because they have also been affected in some way by the offence, and because they care about one of the primary participants" (p. 97).

FGC practices involve extensive preconference preparation with the assistance of a facilitator and ultimately allows for family members of the victim and offender to meet in person to express their thoughts and feelings as a way to heal the pain of wrongdoing. FGC has grown in popularity across the United States. The practice was discussed in $32.9 \%(n=25)$ of the articles reviewed. It has been utilized with serious criminal acts and repeat offenders (Hillian et al., 2004) and domestic violence (Curtis-Fawley \& Daly, 2005; Grauwiler \& Mills, 2004; Coates, Umbreit, \& Vos, 2003), and is more commonly applied as a way to achieve justice in child welfare situations (Adams \& Chandler, 2003; Pennell \& Burford, 2000; Neff, 2002).

The increased interest in FGC has been correlated by MerkelHolguin (2004) to the expansion of family-centered and strengthsbased practices in the social work profession. According to van Wormer (2003), FGC is consistent with empowerment practice and the social work value of self-determination. In the social work literature, for example, all eight journal articles written by social workers in the special edition of the Journal of Sociology and Social Welfare on restorative justice (2002) mention FGC.

Unfortunately, some authors reported concerns regarding the limited use of FGC among social workers. Smith and Stewart (1997) expressed concern FGC is not implemented properly by social workers involved in the criminal justice system due to high caseloads and self-perceived lack of influence. Merkel-Holguin (2004) reported, "Most FGC initiatives are marginalized by limited funding, administrative support, and staffing. This translates into few families having the opportunity to participate in FGCs" (p. 164). Social workers may fail to refer families for FGC due to concerns about confidentiality and anticipated increased workload associated with the practice. Despite these cautions, FGC remains a rapidly expanding restorative justice approach to crime.

\section{Peacemaking Circles}

Peacemaking circles, sometimes called sentencing or talking circles, are a method of communication and problem solving derived from aboriginal and Navajo traditions as a community-based way to resolve conflict (Boyes-Watson, 2005). The use of restorative justice as a means of repairing harm to the victim and community is understood as a societal activity. Van Ness (2004) described peacemaking circles as the "most inclusive process" of the three practices of restorative justice (p. 98). In these egalitarian circles, community members, victims, offenders, families and friends, and a facilitator (also known as a circle keeper) speak in a nonjudgmental way with the aid of a talking piece. The circle keeper may be a criminal justice professional-a judge, a respected community elder (Hillian et al., 2004), or a social worker (van Wormer, 2004). Many of the qualities of the circle keeper detailed by Coates, Umbreit, and Voss (2003) are consistent with social work practice, including a nonjudgmental approach, good listening skills, empathy, respect, patience, and understanding.

Petrunik (2002) provides excellent case examples of how peacemaking circles can be successfully applied in a "community of faith" (p. 503) with the use of Mennonite and Baptist church leaders as circle keepers. A few articles in our review offered step-by-step descriptive analyses of peacemaking circles and the establishment of a restorative justice program (see Cesaroni, 2001, and Coates et al., 2003). These "how to" articles are of tremendous educational value to novice restorative justice practitioners. However, only $18.4 \%(n=14)$ of the articles we reviewed discussed this specific type of restorative justice.

Peacemaking circles take extensive time and financial resources to prepare and implement, and hence, are often criticized (Hillian et al., 2004; Coates et al., 2003). There is an emphasis in peacemaking circles on the use of societal resources and community involvement that may be utilized in the practice of healing (White, 2003). Consequently, peacemaking circles are dependent on the active involvement of volunteer community members committed to improving society. Whitehead \& Braswell (2000) critique the practice, stating circles create unrealistic "nostalgic visions of a community that no longer exists" (p. 216). Whitehead and Braswell further state, "To expect and assume the existence of community in this context is at best difficult and at worst absurd" (p. 217). This criticism may reflect policy limitations of implementing this restorative justice approach.

\section{Religion and Spirituality}

The values inherent in restorative justice have a spiritual and/or religious basis. Spirituality is a broader expression of the relationship with the transcendent, whereas religion is the creedal expression of faith within the context of a social institution. Canda and Furman (1999) define the spiritual as

the person's search for a sense of meaning and morally fulfilling relationships between oneself, other people, the encompassing universe, and the ontological ground of existence, whether a person understands this in terms that are theistic, atheistic, nontheistic, or any combination of these. (p. 44)

Religion, on the other hand, is an institutional and formalized ritualistic belief system (Whitehead \& Braswell, 2000). In our 
review, we found some authors focused on the spiritual context of restorative justice whereas others described restorative justice in a religious framework. Spirituality or religion were included in $20 \%$ $(n=15)$ of the reviewed articles.

Mennonites and restorative justice practitioners from other religious traditions in the United States and Canada experimented with VOM programs for many years, and those efforts were later used as models for programs throughout the world (Zehr, 2002). Restorative justice initiatives are quite prevalent in a range of religious denominations throughout the United States, including Mennonite, Presbyterian, United Methodist, Episcopal, Baptist, Unitarian Universalist, and Ecumenical.

Hanneman and Misleh (2003) talk specifically about the role of religious church bodies in furthering the practice of restorative justice. For example the 2000 statement by the United States Catholic Bishops "Responsibility, Rehabilitation and Restoration: A Catholic Perspective on Crime and Criminal Justice" identifies a clear shift from the prevailing societal approach toward crime to restorative justice practices in which the needs for community safety and victim assistance, and forgiveness of the offender, are stressed (Hanneman \& Misleh, 2003). A key statement in the document is, "We will not tolerate the crime and violence that threatens the lives and dignity of our sisters and brothers, and we will not give up on those who have lost their way. We seek both justice and mercy." (Hanneman \& Misleh, 2003, p. 120). This statement epitomizes the restorative justice emphasis on community, victim, and offender with an emphasis on the value of spiritual healing from a crime.

The Catholic Church's entreaty for mercy or forgiveness of the offender is echoed by Lane (2004). Lane gives an autobiographical account (the only such account in all of the articles reviewed) that chronicles the kidnapping and murder of her youngest daughter and the author's spiritual journey from hate to healing. The author relates how she was eventually able to turn her own anger into forgiveness. Through her experiences, she became a founding board member of Murder Victims' Families for Reconciliation and of Journey of Hope ... From Violence to Healing, national organizations led by and composed primarily of family members of murder victims who oppose the death penalty and promote forgiveness of offenders. Lane uses the principles of restorative justice in her prison ministry work.

In contrast, one social work scholar's perspective on restorative justice contends forgiveness is not an essential component of a successful outcome of the use of restorative justice practices (van Wormer, 2002), but communal healing may be achieved with the approach. Van Wormer and Berns (2004) emphasize spiritual pain associated with crime and potential loss of religious faith. These authors discuss the role of the religious institution in recovering from wrongdoings.

Unlike the adversarial criminal justice process, with restorative justice the offender is called on to explain himself to the victim and community and often to begin to make amends .... For the female survivor ... support by the church and community are vital for her recovery. (van Wormer \& Berns, 2004, p. 64)

Probation is widely used in the criminal justice system, yet little has been written about the possibility of applying spiritual principles to this practice. Whitehead and Braswell (2000) identify restorative justice as a spiritual approach that would put emphasis on the victim, enhance offender competency, and involve the community in the determination and implementation of justice. The authors favor a spiritual approach to justice involving a personal transformation through a spiritual journey, which can include meditation, yoga, the path of service to others, and the meaning of probation to the offender. As Whitehead and Braswell (2000) indicate,

What if officers, prison or probation, instead sat down with offenders and talked to them about their lives? The three fundamental questions of human existence-Who am I? Where am I going? and Why? have been discussed by philosophers, theologians, and social analysts throughout the ages. (p. 224)

Whitehead and Braswell (2000) indicate the constraints of asking these questions in terms of proselytizing and violating individual freedom of religious choice can be problematic, but the prevalence of social workers in the field of probation offers the opportunity to implement the spiritual dimension of practice approaches in relation to crime.

\section{An Overview of Research on Restorative Justice in the Social Work Literature}

Although Smith and Stewart proclaimed in 1997, "Suddenly, it seems everyone is committed once again to restorative justice" (p. 107), research on the topic remains an aberration. Although $42.1 \%(n=32)$ of the articles reviewed had some mention of restorative justice research, half of these simply identified the need for further studies to evaluate both long- and short-term effects. One study (Presser \& VanVoorhis, 2002) provided program evaluation; one article detailed a pilot study for a restorative justice program (Helfgott, Lovell, Lawrence, \& Parsonage, 2000); and Bradshaw and Umbreit (2003) offered a quantitative measurement tool to describe satisfaction with restorative justice practices. Clearly, social work research on restorative justice is conspicuous by its absence.

There are a number of reasons why so little research has been completed on restorative justice to date. Most importantly, it is extremely difficult to evaluate restorative justice programs due to each program's unique organization, structure, and participant involvement. Only one quantitative standardized instrument to assess restorative justice outcomes was found in all the articles reviewed. Bradshaw and Umbreit (2003) developed the Victim Satisfaction with Offender Dialogue Scale (VSODS). This measurement tool is reported by its authors to have a high degree of internal consistency and to produce a reliable overall estimation of victim satisfaction. However, the instrument does not assess offender or community satisfaction with restorative justice practices, nor does it measure recidivism. Although Bradshaw and Umbreit report the VSODS may be used to compare satisfaction between restorative justice programs, the unique needs of victim, offender, and community may make the diversity of programs very difficult to compare and research.

Presser and VanVoorhis (2002) described concerns with internal validity due to the selection bias of research participants. Prior demographic research regarding participation in restorative justice practices determined Caucasian families are disproportionately represented in FGC in comparison to minority populations 
(Merkel-Holguin, 2004). Additionally, the typical participating victim in the United States is a Caucasian male, in his mid-30s, and the offender is most frequently a Caucasian or Latino male teenager charged with a property crime (Merkel-Holguin, 2004). Hence, many of the studies conducted to date are suspected to have involved a homogenous sample of Caucasian victims and juvenile offenders. Not surprisingly, the majority of reviewed studies focused on male juvenile offenders.

Face-to-face contact, which typically occurs in VOM programs, appears to be both a strength and barrier to participation in restorative justice. On the one hand, prior research has determined that meeting face-to-face is the most satisfying aspect of participating in restorative justice practices (Umbreit, Coates, \& Warner-Roberts, 2000). However, getting victims, offenders, and communities to agree to participate in restorative justice programs has been documented as a difficult process. Face-to-face, in-person contact between victim, offender, and community is required for VOM, FGC, and peacemaking circles. Yet the very core of these restorative justice practices may be psychologically overwhelming or threatening for potential participants.

Merkel-Holguin (2004) found a high percentage of families referred for face-to-face conferencing decline the option to participate. Umbreit, Coates, and Warner-Roberts (2000) determined

\section{Social workers are in a unique position to assist crime victims, offenders, communities, and families...by way of offering in-depth, humanistic, and professional exploration of the meaning of wrongdoing.}

only $40 \%$ of those referred to mediation in the United States followed through with a face-to-face restorative justice meeting. It is therefore apparent in this systematic review that although face-toface contact may result in positive satisfaction reports, it may also be a significant barrier to participating in restorative justice programs.

Qualitative methodologies resonated in much of the literature under review. This approach is consistent with the complex, sensitive, and nonlinear scope of restorative justice practices (Presser \& VanVoorhis, 2002). One quarter $(25 \%, n=20)$ of all reviewed articles contained case examples or personal testimonials (Helfgott et al., 2000; Cerasoni, 2001; Gavazzi, Yarcheck, Wasserman, \& Partridge, 2000; Lane, 2004). The humanistic emphasis on "making the justice process human" (Umbreit et al., 2000, p. 222) allows victims and offenders the opportunity to tell their stories and to personalize "a typically ineffective, detached justice system" (p. 223). Bazemore (1999) provided clear voices expressing dissatisfaction in focus groups of victims of juvenile crime who did not participate in restorative justice approaches in contrast with the hope for reparation and restitution through the use of restorative justice. Hence, there is great value found in the use of case examples and narrative inquiry as qualitative tools for understanding the process and impact of restorative justice practices.

Presser and VanVoorhis (2002) articulated a primary impediment to research on restorative justice requires the evaluative researcher to be trained in restorative justice practices and principles. In order to fully capture and understand the subjective meaning, outcomes, and impact of restorative justice on a victim, offender, or community, Presser and VanVoorhis state the researcher must hold an insider's perspective on the process itself. The need for researchers to be trained in restorative justice also helps explain the dearth of a social work presence in the relevant literature. Whereas there has been a steady increase in the number of publications on restorative justice in the criminal justice field (including corresponding research and literature on the topic), the roles of social workers as authors, researchers, and participants in restorative justice practices have been significantly limited to the authors repeatedly mentioned in this review (e.g., Katherine van Wormer and Mark Umbreit).

One area the social work literature poorly evaluated was the frequency of repeat offenses by offenders who were involved in restorative justice efforts. Few articles in our review of social work databases directly addressed recidivism following participation in restorative justice. When authors did tackle this topic (Wong, 1999; Bazemore, 1999), the literature primarily focused on reoffending juveniles. Nugent and Paddock (1996) found juvenile offender participation in VOM is associated with lower rates of recidivism after 1 year. In a 2001 replication study by Nugent, Umbreit, Wiinamaki, \& Paddock regarding the impact of VOM on recidivism, juvenile reoffense rates of those who participated in VOM were found to be $32 \%$ lower than juvenile offenders who did not participate in VOM. Additionally, those offenders who did reoffend committed a less severe offense.

More recently Nugent, Williams, and Umbreit (2004) and Jainchill, Hawke, and Messina (2005) researched 5-year outcomes of restorative justice intervention among juvenile offenders and found similar results. Research studies addressing outcomes of restorative justice are widely prevalent in the criminal justice literature, yet social work's role or voice in these articles were minimally captured in this review's search of articles in Social Services Abstracts and Social Work Abstracts.

\section{Social Work Education and Restorative Justice}

Based on this systematic review of the restorative justice literature, social work educators have written little about restorative justice as it relates to social work education. Only two articles specifically addressed educating social workers on the topic. Young and LoMonaco (2001) discussed the extent to which content from human behavior in social environment, practice, research, and social welfare policy can be used in work with offenders in the context of corrections. Yet nothing was included in the article about restorative justice other than a reference to a restorative justice Web site. Van Wormer (2006) indicated at the annual meetings of the Council on Social Work Education there was one paper on restorative justice in 2002 and none in 2003 and 2004. Van Wormer (2006) reported her submission in 2003 was rejected as "not relevant to social work education" (p. 58). Given the general lack of interest among social work educators in the topic of restorative justice, students in schools of social work are not learning about restorative justice and its attendant practice skills. Although 
restorative justice may be embedded within discourse of victimology course content, increased education on this humanistic approach to crime is needed in the field of social work. The one exception (and model example) to this educational deficit is the work of the Center for Restorative Justice and Peacemaking affiliated with the School of Social Work at the University of Minnesota.

\section{Implications for Practice}

The role of social workers in restorative justice programs remains largely unknown. This review of the literature revealed only $22.4 \%$ $(n=17)$ of our articles from Social Work Abstracts and Social Services Abstracts databases contained information about the role of social workers in restorative justice programs and practices. In contrast, the criminal justice literature during the same dates (February 1995 to January 2007) of our systematic review contained an abundance of material on the topic with more than double the number of articles on restorative justice $(n=225$ in the Criminal Justice Periodical Index).

Social workers are in a unique position to assist crime victims, offenders, communities, and families impacted by crime to deal with the biopsychosocial and spiritual impact of crime and the potential for healing by way of offering in-depth, humanistic, and professional exploration of the meaning of wrongdoing. The profession addresses human behavior from a biopsychosocial and spiritual perspective concordant with restorative justice. Despite the profession's fit with and belief in restorative justice, social workers have been criticized as lacking the training and knowledge to undertake restorative justice practices effectively (Baldry, 1998). Social workers offer contributions to micro, mezzo, and macro practice, but have yet to fully invest in this important area of practice. Hence, the increased involvement, commitment, education, training, and research participation of social workers in restorative justice practices is greatly needed.

Petrosino (2005) also raised a commonly voiced question regarding restorative justice: How do we know it "works"? Due to the lack of social work-related longitudinal studies on the longterm effects of restorative justice (e.g., recidivism, psychological impact on victims, community change) further studies are needed to monitor the effects and impact of restorative justice programs. In evaluating the effectiveness of restorative justice programs in the criminal justice field, Latimer, Dowden, and Muise (2005) indicate in their meta-analysis that the effectiveness of researching restorative justice practices is heavily biased by those victims, offenders, and communities that allow themselves to be studied. Presser and VanVoorhis aptly stated, "The future viability of restorative justice is largely depending on the findings of evaluation research" (2002, p. 162). This observation certainly applies to both the fields of criminal justice and social work.

From its origin as a profession, social work seems to have strayed from an interest in building models of community rehabilitation and justice. Restorative justice practices offer the social work profession an excellent opportunity to return to its historical roots. We believe the social work profession is poised to be a natural choice for aiding this three-dimensional approach to crime and wrongdoing. Restorative justice principles of empathy, empowerment, and community involvement coincide with social work values and the profession's code of ethics (van Wormer, 2004). Additionally, the social work profession has the aptitude, infrastructure, and capacity to serve as a bridge between the presently held traditions of justice and an evolving, more holistic and participatory model of restorative justice. We hope as the restorative justice movement grows in relevance and social work educators see its importance in addressing the micro, mezzo, and macro impact of crime, restorative justice principles and practices will become more commonly taught in schools of social work. Social workers could then provide a stronger presence in the field of restorative justice and offer increased participation in the healing process to victims, offenders, and communities.

\section{References}

Adams, P., \& Chandler, S. (2003). Responsive regulation in child welfare: Systematic challenges to mainstreaming the family group conference. Sociology and Social Welfare, 31(1), 93-116.

Addams, J. (1912). Twenty years at Hull House. New York: Macmillan.

Arrigo, B. (2004). Rethinking restorative and community justice: A postmodern inquiry. Contemporary Justice Review, 7, 91-100.

Baldry, A. (1998). Victim-offender mediation in the Italian juvenile justice system: The role of the social worker. The British Journal of Social Work, 28, 729-744.

Bazemore, G. (1999). Crime victims, restorative justice and the juvenile court: Exploring victim needs and involvement in the response to youth crime. International Review of Victimology, 6, 295-320.

Boyes-Watson, C. (2005). Seeds of change: Using peacemaking circles to build a village for every child. Child Welfare, 84(2), 191-208.

Bradshaw, W., \& Umbreit, M. (2003). Assessing satisfaction with victim services: The development and use of the Victim Satisfaction with Offender Dialogue Scale. International Review of Victimology, 10, 71-83.

Braithwaite, J. (2002). Restorative justice and responsive regulation. New York: Oxford University Press.

Braithwaite, J. (2004). Families and the republic. Journal of Sociology and Social Work, 31, 99-215.

Canda, E., \& Furman, L. (1999). Spiritual diversity in social work practice: The heart of help. New York: The Free Press.

Cerasoni, C. (2001). Releasing sex offenders into the community through "Circles of support"-A means of reintegrating the "Worst of the Worst." Journal of Offender Rehabilitation, 34, 85-98.

Chatterjee, P. (2002). Two tails of justice. Families in Society: The Journals of Contemporary Human Services, 83, 374-386.

Coates, R., Umbreit, M., \& Vos, B. (2003). Restorative justice circles: An exploratory study. Contemporary Justice Review, 6, 265-278.

Curtis-Fawley, S., \& Daly, K. (2005). Gendered violence and restorative justice: The views of victim advocates. Violence Against Women, 11(5), 603-638.

Dofgoff, R., Loewenberg, F., \& Harrington, D. (2005). Ethical decisions for social work practice. Belmont, CA: Brooks/Cole.

Gavazzi, S., Yarcheck, C., Wasserman, D., \& Partridge, C. (2000). A balanced and restorative approach to juvenile crime: Programming for families of adolescent offenders. Family, Crime \& Criminal Justice, 2, 381-405.

Golder, S., Ivanoff, A., Cloud, R., Besel, K., McKiernan, P., Bratt, E., \& Bledsoe, L. (2005). Evidence-based practice with adults in jails and prisons: Strategies, practices, and future directions. Best Practices in Mental Health, 1, 100-132.

Grauwiler, P., \& Mills, L. G. (2004). Moving beyond the criminal justice paradigm: A radical restorative justice approach to intimate abuse. Journal of Sociology and Social Welfare, 31(1), 49-69.

Gumz, E. (2004). American social work, corrections and restorative justice: An appraisal. International Journal of Offender Therapy and Comparative Criminology, 48, 449-460.

Hanneman, E., \& Misleh, D. (2003). Emerging issues: The faith communities and the criminal justice system. Journal of Religion and Spirituality in Social Work, 23(1/2), 111-131.

Helfgott, J., Lovell, M., Lawrence, C., \& Parsonage, W. (2000). Results from the pilot study of the Citizens, Victims, and Offenders Restoring Justice program at the Washington State Reformatory. Journal of Contemporary Criminal Justice, $16,5-31$.

Hillian, D., Reitsma-Street, M., \& Hackler, J. (2004). Conferencing in the youth criminal justice act of Canada: Policy development in British Columbia. Canadian Journal of Criminology and Criminal Justice, 46, 343-366.

Hollis, F. (1964). Casework: A psychosocial therapy. New York: Random House.

Jainchill, N., Hawke, J., \& Messina, M. (2005). Posttreatment outcomes among adjudicated adolescent males and females in modified therapeutic community treatment. Substance Use \& Misuse, 40, 975-996. 
Lane, M. (2004). From fury to forgiveness. Journal of Religion and Spirituality in Social Work, 23, 159-172.

Latimer, J., Dowden, C., \& Muise, D. (2005). The effectiveness of restorative justice practices: A meta-analysis. Ottawa: Canada Department of Justice Research and Statistics Division.

Merkel-Holguin, L. (2004). Sharing power with the people: Family group conferencing as a democratic experiment. Journal of Sociology \& Social Welfare, 31, 155-173.

Nellis, M. (1995). Probation values for the 1990's. Howard Journal of Criminal Justice, 34, 19-44.

Nugent, W., \& Paddock, J. (1996). Evaluating the effects of a victim-offender reconciliation program on reoffense. Research on Social Work Practice, 6, 155-178.

Nugent, W., Umbreit, M., Wiinamaki, L., \& Paddock, J. (2001). Participation in victim-offender mediation and reoffense: Successful replications? Research on Social Work Practice, 11, 5-23.

Nugent, W., Williams, M., \& Umbreit, M. (2004). Participation in victim-offender mediation and the prevalence of subsequent delinquent behavior: A metaanalysis. Research on Social Work Practice, 14, 408-416.

Pennell, J. \& Burford, G. (2000). Family group decision making: Protecting children and Women. Child Welfare, 79(2), 131-158.

Petrosino, A. (2005). From Martinson to meta-analysis: Research reviews and the U.S. offender treatment debate. Evidence \& Policy, 1, 149-171.

Petrunik, M. (2002). Managing unacceptable risk: Sex offenders, community response, and social policy in the United States and Canada. International Journal of Offender Therapy and Comparative Criminology, 46, 483-511.

Presser, L., \& VanVoorhis, P. (2002). Values and evaluation: Assessing processes and outcomes of restorative justice programs. Crime \& Delinquency, 48, 162-188.

Ruth-Heffelbower, D. (2006). Learn about victim-offender mediation. Retrieved March 10, 2007 from www.voma.org/abtvom.shtml

Smith, D., \& Stewart, J. (1997). Probation and social exclusion. Social Policy \& Administration, 31(5), 96-115.

Specht, H., \& Courtney, M. (1994). Unfaithful angels: How social work has lost its mission. New York: The Free Press.

Stinchcomb, J., \& Fox, V. (1999). Introduction to corrections (5th ed.). Upper Saddle River, NJ: Prentice Hall.

Towle, C. (1965). Common human needs. New York: National Association of Social Workers.

Tschudi, F., \& Reichelt, S. (2004). Conferencing when therapy is stuck. Journal of Systemic Therapies, 23, 38-52.

Umbreit, M., Bradshaw, W., \& Coates, R. B. (1999). Victims of severe violence meet the offender: Restorative justice through dialogue. International Review of Victimology, 6(4), 321-343.

Umbreit, M., Vos, B., \& Coates, R. (2004) Victim-offender mediation: Three decades of practice and research. Conflict Resolution Quarterly, 22, 279-303.

Umbreit, M., Coates, R., \& Warner-Roberts, A. (2000). The impact of victimoffender mediation: A cross-national perspective. Mediation Quarterly, $17,215-229$.
Van Ness, D. (2004). Justice that restores: From impersonal to personal issues. Journal of Religion and Spirituality in Social Work, 23, 93-109.

van Wormer, K. (2002). Restorative justice and social work. Social Work Today, 2(1), 17-19.

van Wormer, K. (2003). Restorative justice: A model for social work practice with families. Families in Society: The Journal of Contemporary Human Services, $84,441-448$

van Wormer, K. (2004). Restorative justice: A model for personal and societal empowerment. Journal of Religion \& Spirituality in Social Work, 23, 103-120.

van Wormer, K. (2006). The case for restorative justice: A crucial adjunct to the social work curriculum. Journal of Teaching in Social Work, 26, 57-69.

van Wormer, K., \& Bednar, S. (2002). Working with male batterers: A restorativestrengths perspective. Families in Society: The Journal of Contemporary Human Services, 83, 557-565.

van Wormer, K., \& Berns, L. (2004). The impact of priest sexual abuse: Female survivors' narratives. Affilia, 19, 53-67.

Walgrave, L. (1995). Restorative justice for juveniles: Just a technique or a fully fledged alternative? Howard Journal of Criminal Justice, 34(3), 228-249.

White, R. (2003). Communities, conferences and restorative justice. Criminal Justice, 3, 139-160.

Whitehead, J., \& Braswell, M. (2000). The future of probation: reintroducing the spiritual dimensions into correctional practice. Criminal Justice Review, $25,207-233$.

Wong, D. (1999). Culturally specific causes of delinquency: Implications for juvenile justice in Hong Kong. Asian Pacific Journal of Social Work, 9, 98-113.

Young, D. S., \& LoMonaco, S.W. (2001). Incorporating content on offenders and corrections into social work curricula. Journal of Social Work Education, 3 7, 475-491.

Zehr, H. (1990). Changing lenses: A new focus for crime and justice. Scottdale, PA: Herald.

Zehr, H. (2002). The little book of restorative justice. Intercourse, PA: Good Books.

Edward J. Gumz, PhD, LCSW, is associate professor, School of Social Work, Loyola University of Chicago. Cynthia L. Grant, LCSW, ACSW, is adjunct faculty, School of Social Work, Loyola University of Chicago. Correspondence regarding this article should be sent to the first author at egumz@luc.edu or School of Social Work, 820 N. Michigan Ave., Chicago, IL 60611.

Manuscript received: June 11, 2007

Revised: November 8, 2007

Accepted: November 9, 2007 